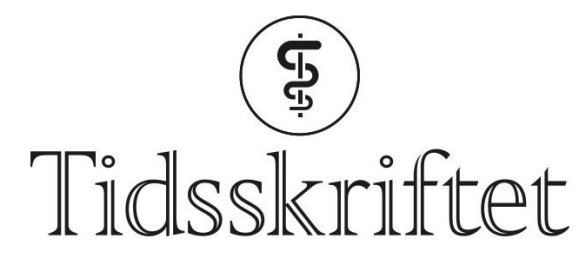

DEN NORSKE LEGEFORENING

\title{
Rettelse: Har et «filleristet spedbarn» alltid vært filleristet?
}

RETTELSE

KNUT WESTER

Tidsskr Nor Legeforen 2018; 138: 1422-4.

I Tidsskriftet nr. 15/2018, s. 1424, skal referanse 4 være:

Binenbaum G, Mirza-George N, Christian CW et al. Odds of abuse associated with retinal hemorrhages in children suspected of child abuse.J AAPOS 2009; 13:268-72.

Videre skal det på samme side stå:

Forhøyet intrakranialt trykk formidles via vceskeskjeden rundt synsnerven, som hos spedbarn er meget kort, til øyebunnen, noe som gir blødninger. Heller ikke utbredte retinale blødninger kan anses som ensbetydende med filleristing $(10,19,20)$.

Vi beklager feilen, den er rettet på nett.

Publisert: 27. september 2018. Tidsskr Nor Legeforen. DOI: 10.4045/tidsskr.18.o742

(C) Tidsskrift for Den norske legeforening 2020. Lastet ned fra tidsskriftet.no 